\title{
INFILTRATION OF WATER AND SALINITY IN LUVISSOLO OF THE BRAZILIAN SEMIARID CULTIVATED WITH DIFFERENT MANAGEMENT SYSTEMS
}

Francisco Sandro Rodrigues Holanda ${ }^{1}$, Renisson Neponuceno Araújo Filho ${ }^{2}$, Alceu Pedrotti ${ }^{1}$, Tiago Oliveira $\operatorname{Santos}^{3} \&$ Heide Vanessa Souza Santos ${ }^{4}$

${ }^{1}$ Universidade Federal de Sergipe. E-mail: fholanda@infonet.com; alceupedrotti@gmail.com.br

${ }^{2}$ Universidade Federal de Pernambuco. E-mail: nepoaraujo@gmail.com

${ }^{3}$ Universidade Federal Rural de Pernambuco. E-mail: tiagoosantos@yaoo.com.br

${ }^{4}$ Universidade Federal de Minas Gerais. E-mail: heidee.vanessa@ gmail.com.br

\section{ABSTRACT}

The objective of this study was to evaluate the basic infiltration rate (IB), the cumulative infiltration (CI) and electrical conductivity (EC) of saturated-paste extract, in a Carbonático vértico cultivated under tillage systems such as conventional tillage (CT), the minimum tillage (MT) and notillage (NT), on crop rotation. After two and a half years of field research, the infiltration rate and cumulative infiltration was higher in NT, followed by MT and CT. Higher water infiltration rates are related to the sites where conservation practices were adopted, improving soil structure.

Keywords: Basic infiltration rate, tillage systems, salinization

\section{INFILTRAÇÃO DE ÁGUA E SALINIDADE EM LUVISSOLO DO SEMIÁRIDO CULTIVADO COM DIFERENTES SISTEMAS DE MANEJO}

\section{RESUMO}

O objetivo deste estudo foi avaliar a taxa básica de infiltração (IB), a infiltração acumulada (IC) e a condutividade elétrica (CE) de extrato de pasta saturada, em um Carbonático vértico cultivado sob sistemas de preparo convencional (CT), cultivo mínimo (MT) e plantio direto (NT), na rotação de culturas. Após dois anos e meio de condução dos trabalhos, IB e CI apresentaram maiores resultados na área manejada com NT, seguidas das áreas de MT e CT. As concentrações de sais indicam solo 
considerado não-salino. Maiores taxas de infiltração são atribuídas aos locais com práticas conservacionistas, que melhoram a estruturação do solo.

Palavras-chave: Velocidade de infiltração básica, sucessão de culturas, salinização

\section{INTRODUCTION}

The Brazilian northeastern semiarid region presents an irregular water regime, which by its own definition has water as the most limiting factor to obtaining high agricultural productivity (ANTONINO et al., 2000). Rainfall sparse, irregular over the years, concentrated in a short period of time (three to four months per year), with intensity and varying frequenciesreinforce the importance of using technologies to consider climate limitations deserving emphasis on irrigation, which will act as provider of the necessary supply of water for crops (MACHADO et al., 2007). Even considering the adversities are areas with good availability of surface and groundwater, as well as resources of soil and amount of solar energy suitable to develop irrigated agriculture in competitive conditions with other semi-arid regions of the world (AGUIAR NETTO et al., 2006a, 2006b).

With the creation of irrigated perimeters, the limitation of the lack of rainfall in the semi-arid region was solved in places where there is water availability to guarantee this type of use, but several other issues resulting from poor planning and inadequate management of irrigation water at various points of the Northeastern region have led to problems salinity soil resulting from the higher water table critical levels (VALLADARES \& FARIA, 2004; FERREIRA et al., 2006). The occurrence of salinization is subject to the processes of evaporation and capillary rise, called efflorescence, which in turn depend on the climatic and hydraulic characteristics (KOSUTIC et al., 2001) and the actual geological formation that can carry a high load of source material salts or deeper layers of soil to the surface, or be caused by improper handling of irrigation water (BRASILEIRO, 2009).

The salinization and / or sodification is a problem with economic, social and ecological consequences (FERREIRA et al., 2006) and its effect on soil is in its action on the grouping or arrangement of particles, where physical properties as aggregate stability, particle dispersion, permeability and infiltration are more influenced by the types of exchangeable cations in the soil (GHEYI et al., 1997; CHAVES et al. 2006). According to Mendes et al. (2008), shallow soils and light to medium texture, irrigated with low efficiency, are salinated in a few years of its operation with irrigation. 
The process of salting and / or sodification, is more frequent in semi-arid regions, due to climatic conditions (high evaporation and temperature and low humidity) that require high demands of water (2 to 4 times the annual rainfall) for irrigation, depending on the growing season and water requirements of cultivated species (MACEDO \& MENINO, 1998; LOPES et al., 2008).

While the accumulation of soluble salts makes the soil flocculated, friable and well permeable, the increase of exchangeable sodium may make it compacted in dry, dispersed and sticky conditions in wet conditions (GHEYI et al., 1991; RUIZ et al., 2006). Although the high exchangeable sodium content is important in impairment of permeability of the soil water, other factors can assume even greater importance.

The rate of infiltration is controlled by the pore size and distribution and continuity of the paths formed by them in the ground (KUTÍLEK, 2004). In this way the low infiltration capacity can be the result of low permeability of the soil caused by the lack of secondary pores or macropores and the sufficient presence of fine particles of the soil that limit the size of the primary pores. Understanding the relationships between the pore structure induced by the preparation and infiltration is of crucial importance to predict water flow characteristics and solutes in the soil profile (LIPIEC et al., 2006).

The main problems caused by soil salinization are the reduction of the osmotic potential of the soil solution, reducing its availability of water and accentuating the ionic toxicity to the plants (LIMA et al., 2005; SANTANA et al., 2007), hindering the passive transport of water from the soil to the plants and, consequently, the magnitude of the problem of water scarcity to the plant. In general, it can be said that, due to the affinity of the salts with the water, the plants have to exert greater imbibition force to extract from the soil the solution (salts and water) that will be used for their vital activities causing an energetic decrease that will influence their development and, consequently, productivity (DIAS et al., 2005; LACERDA et al., 2011).

The objective of this study was to evaluate the basic infiltration rate (IB), the cumulative infiltration (CI) and electrical conductivity (EC) of saturated-paste extract, in a Luvissolo Crômico Carbonático Vértico cultivated under tillage systems such as conventional tillage (CT), the minimum tillage (MT) and no-tillage (NT), on crop rotation.

\section{MATERIAL AND METHODS}

The present work was conducted on the California Irrigated Perimeter (09 $42^{\prime} \mathrm{S}$ e $\left.37^{\circ} 49^{\prime} \mathrm{W}\right)$, characterized by the sprinkler irrigation system, located in the municipality of Canindé do São Francisco, 236 
in the extreme northwest of the State of Sergipe, in the semiarid region of Brazil. The soil classification of the area was performed with the opening of a trench with the dimensions $2.0 \times 1.10 \times 3.0 \mathrm{~m}$, where samples of soil with a deformed and undisturbed structure were also collected in each horizon. The horizons samples were prepared and sent for physical and chemical analysis.

The physical analyses with the deformed samples were determined the particle size distribution by the method of bouyoucos (EMBRAPA, 1997). Samples undisturbed bulk density (BD) by the volumetric ring method (EMBRAPA, 1997).

To determine the chemical analyses, there were measured the $\mathrm{pH}$ in water in the ratio $1: 2.5$, shaking for one minute and one hour of reaction time (EMBRAPA, 2009). The exchangeable cations were analyzed according to Embrapa (2009), being the $\mathrm{Al}^{3+}, \mathrm{Ca}^{2+} \mathrm{e} \mathrm{Mg}^{2+}$ extracted with solution $\mathrm{KCl} 1$ mol L ${ }^{-1} \cdot \mathrm{Ca}^{2+}$ and $\mathrm{Mg}^{2+}$ were determined by atomic absorption spectrophotometry, and $\mathrm{Al}^{3+}$ exchangeable, or exchangeable acidity, was determined by titration with solution $\mathrm{NaOH} 0,025 \mathrm{~mol} \mathrm{~L}^{-1}$, in the presence of the blue bromothymol indicator $(0.1 \%)$. $\mathrm{Na}^{+}$e o $\mathrm{K}^{+}$was extracted with solution Mehlich-1 and determined by flame emission photometry.

The potential acidity $(\mathrm{H}+\mathrm{Al})$ was extracted with buffered solution of calcium acetate $0.5 \mathrm{~mol} \mathrm{~L}$ $1(\mathrm{pH} 7.1-7.2)$ and determined by titration with $\mathrm{NaOH} 0.025 \mathrm{~mol} \mathrm{~L}^{-1}$ in the presence of phenolphthalein indicator $10 \mathrm{mg} \mathrm{L}^{-1}$ (EMBRAPA, 2009). The sum bases (SB) was calculated with the sum of exchangeable cations; cation exchange capacity (CEC) was calculated by summing the base (BS) and $(\mathrm{Al} 3+\mathrm{H}+)$; base saturation $(\mathrm{V})$ was calculated as the ratio SB: CEC and multiplied by 100 and aluminum saturation $(\mathrm{m})$ the ratio of $\mathrm{Al}^{3+}$ and $\left(\mathrm{SB}+\mathrm{Al}^{3+}\right)$ multiplied by 100 (EMBRAPA, 2009). The total organic carbon (TOC) was quantified by the Walkley Black method, adapted by Mendonça \& Matos (2005). The taxonomic classification of the soils was made based on the Brazilian Soil Classification System (EMBRAPA, 2013).

The extraction of soil solution was performed in 0-10;10-20 and 20-30 $\mathrm{cm}$ by the preparation of the saturated paste system and extraction vacuum, the procedures of which are described in USSL (1954). The electrical conductivity (EC) was measured in the extract of the saturated paste (EMBRAPA, 2009). To obtain the moisture of the saturated paste where the gravimetric method was used (EMBRAPA, 2007).

The treatments evaluated were the systems conventional tillage (CT), minimum tillage (MT) and no-tillage (NT) in different crop sequences: sweet corn / okra (CO), sweet corn / eggplant (CE), sweet corn / Scarlet Eggplant (CS) and okra / okra (OO). Conventional tillage (CT) was disk plow used as the primary preparation and leveling harrow as secondary preparation. Minimum tillage (MT) was used light 
harrowing, not exceeding $15 \mathrm{~cm}$ superficial of the soil, with partial incorporation of the cultural remains and, consequently, planting of the subsequent crop realized on vegetal remains. No-tillage (NT) was characterized by the non-tilling of the soil, with planting of the culture carried out on the cultural remains of the previous crop, with planter adapted for this cropping system, using herbicides for adequate control of invasive species.

After two and a half years of implantation of experiments testing infiltration tests were conducted by the method of ring infiltrometer (EMBRAPA, 1997) installed in all three cropping systems, and at random. The values for the construction of the accumulated infiltration curves (CI), expressed in mm, which is the amount of water infiltrated during the time elapsed in the test and the basic infiltration velocity (IB), expressed in $\mathrm{mm} \mathrm{h}^{-1}$, which represents the height of the water depth or volume of water that has infiltrated the soil per unit of time.

The experimental design was the randomized blocks (DRB), in a 3 X 4 factorial scheme, with 3 replicates. The results were submitted to ANOVA and the means compared by Tukey test at 5\% significance probability with statistical program SISVAR (FERREIRA, 2011).

\section{RESULTS AND DISCUSSION}

The soil in the area was classified as Luvissolo Crômico Carbonático vértico, predominantly clayey, and formed by structure in the horizon B characterized by medium to large subangular blocks with strong resistance and friable consistency. The profile presented high fertility, according to physicochemical data presented in Table 1.

The system of NT presented higher values of moisture of the saturated paste $(\mathrm{p}<0.05)$, when compared with MT and CT, emphasizing the positive effect of the addition of cultural remains and the non-tilting of the soil in the water retention capacity in the soil (Table 2).

It is known that plants respond distinctly to salinity, Ayers \& Westcot (1994) classify okra culture as sensitive to salinity, while sweet corn and eggplant cultures are moderately sensitive. Similarly, the EC values obtained do not lead to the classification of the soil as saline, since the values of the saturated paste are smaller than $4 \mathrm{dS} \mathrm{m} \mathrm{m}^{-1}$. Thus, in the experimental conditions, there was no damage to crop development due to soil salinity. 
Table 1. Physical and chemical attributes of classified soil, agricultural year 2002 to 2004.

\begin{tabular}{|c|c|c|c|c|c|c|c|c|}
\hline \multirow{2}{*}{ Properties } & \multirow{2}{*}{ Unit } & \multicolumn{7}{|c|}{ Horizons } \\
\hline & & $\overline{A p}$ & $\mathrm{~A} / \mathrm{B}$ & $\mathrm{B} / \mathrm{A}$ & $\mathrm{Bt}_{1}$ & $\mathrm{Bt}_{2}$ & $\mathrm{Bt}_{3}$ & $\mathrm{C} / \mathrm{R}$ \\
\hline$\overline{\mathrm{pH}}(1: 2,5)$ & & 7.2 & 6.6 & 6.6 & 6.7 & 7.0 & 7.1 & 7.0 \\
\hline BS & $\mathrm{cmol}_{\mathrm{c}} \mathrm{dm}^{-3}$ & 20.0 & 23.4 & 33.5 & 34.1 & 35.5 & 30.0 & 26.0 \\
\hline CEC & $\mathrm{cmol}_{\mathrm{c}} \mathrm{dm}^{-3}$ & 20.0 & 23.4 & 33.5 & 34.1 & 35.5 & 30.0 & 26.0 \\
\hline $\mathrm{CEC} \mathrm{pH} 7,0$ & $\mathrm{cmol}_{\mathrm{c}} \mathrm{dm}^{-3}$ & 21.2 & 24.7 & 35.2 & 35.8 & 36.8 & 31.3 & 27.2 \\
\hline $\mathrm{m}$ & $\%$ & 0.0 & 0.0 & 0.0 & 0.0 & 0.0 & 0.0 & 0.0 \\
\hline V & $\%$ & 94.3 & 94.7 & 95.2 & 95.2 & 96.5 & 95.8 & 95.6 \\
\hline TOC & $\mathrm{g} \mathrm{kg}^{-1}$ & 1.2 & 0.7 & 0.7 & 0.7 & 0.8 & 0.7 & 0.3 \\
\hline Sand & $\%$ & 61.0 & 60.0 & 39.0 & 36.0 & 35.0 & 51.0 & 54.0 \\
\hline Clay & $\%$ & 19.0 & 20.0 & 27.0 & 29.0 & 32.0 & 25.0 & 26.0 \\
\hline Silte & $\%$ & 20.0 & 20.0 & 34.0 & 35.0 & 33.0 & 24.0 & 20.0 \\
\hline $\mathrm{EC}$ & $\mathrm{dS} \mathrm{m}^{-1}$ & 0.4 & 1.7 & 1.6 & 1.1 & 0.9 & 0.6 & 0.7 \\
\hline $\mathrm{BD}$ & $\mathrm{kg} \mathrm{m}^{-3}$ & 1.703 & 1.557 & 1.563 & 1.655 & 1.576 & 1.540 & * \\
\hline
\end{tabular}

* Not sampled because it is excessively moist at the time of collection.

Table 2. Average values of moisture saturated paste and soil electrical conductivity in areas subjected to different types of soil preparation, crop year 2002-2004.

\begin{tabular}{|c|c|c|c|c|c|c|}
\hline \multirow{3}{*}{$\begin{array}{l}\text { Depth } \\
(\mathrm{cm})\end{array}$} & \multicolumn{3}{|c|}{ Saturated paste moisture } & \multicolumn{3}{|c|}{ EC Saturated paste } \\
\hline & \multicolumn{3}{|c|}{ 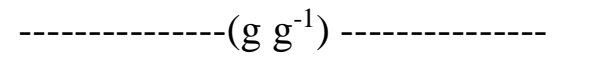 } & \multicolumn{3}{|c|}{ 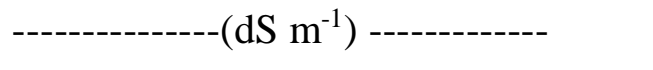 } \\
\hline & NT & MT & CT & NT & MT & $\mathrm{CT}$ \\
\hline $0.0-10.0$ & $0.75 \mathrm{aA}^{1}$ & $0.62 \mathrm{aAB}$ & $0.63 \mathrm{aB}$ & $1.25 \mathrm{aAB}$ & $1.48 \mathrm{aA}$ & $1.01 \mathrm{aB}$ \\
\hline $10.0-20.0$ & $0.72 \mathrm{aA}$ & $0.70 \mathrm{aAB}$ & $0.65 \mathrm{aB}$ & $1.23 \mathrm{aA}$ & $1.12 \mathrm{aAB}$ & $0.95 \mathrm{aB}$ \\
\hline $20.0-30.0$ & $0.74 \mathrm{aA}$ & $0.64 \mathrm{aAB}$ & $0.58 \mathrm{aB}$ & $1.30 \mathrm{aB}$ & $1.63 \mathrm{aAB}$ & $2.53 \mathrm{aA}$ \\
\hline
\end{tabular}

$\mathrm{CV}(\%) \quad 4.93$

\footnotetext{
${ }^{1}$ Means followed by the same lower case letter in the column, and capital letters in the line, do not differ significantly by the Tukey test $(\mathrm{p}<0.05)$. C.V $=$ coefficient of variation.
}

It is observed that due to the maintenance of the cultural remains and the absence of soil rotation or mobilization in the NT system, there was an improvement in the soil infiltration capacity due to the contribution of organic matter. This can be a strategy of prevention or even of recovery of the soil system, 
to the processes of salinization and erosion, as can be identified in Figure 1. Values are perceived IB and CI in the system of NT, with correlation coefficients that present a good fit of the data expressed by high correlation coefficients.

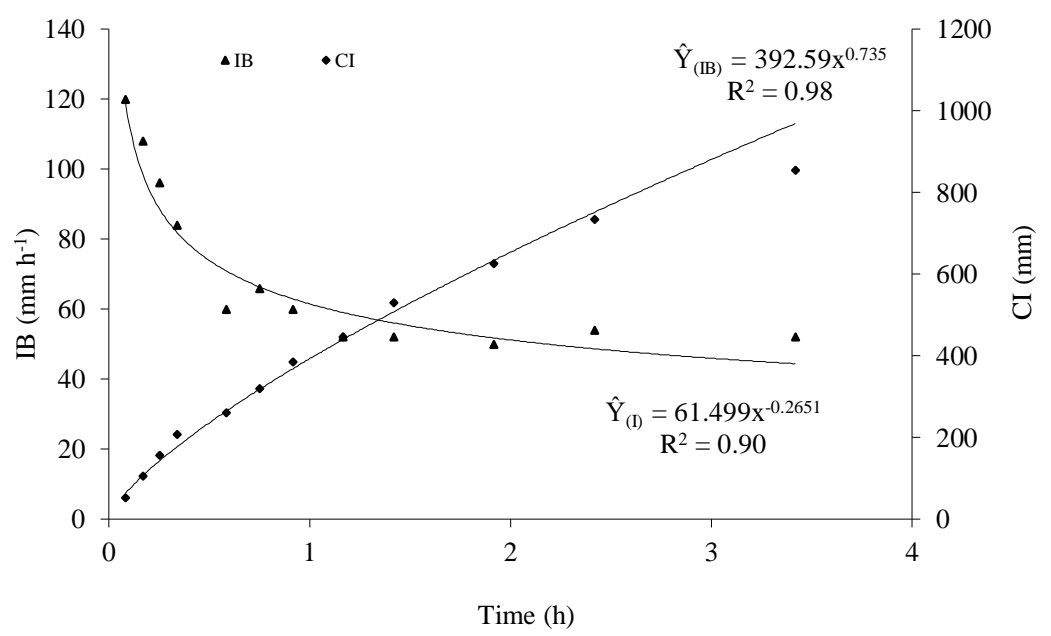

Figure 1. Basic infiltration velocity and accumulated infiltration of soil under no-tillage in the California irrigated perimeter, Canindé do São Francisco, SE, agricultural year 2002 to 2004.

Such behavior can also be explained by the high soil porosity. Studying the behavior of water infiltration in a Luvissolo Crômico Pálico Abrúptico, Silva et al. (2006) found similar values of IB and CI to the system NT. The authors attributed these values to the superficial soil condition provided by their preparation, which favored water infiltration.

The cultivated area in system MT presented intermediate values of IB and CI, ie lower than in NT and higher than in CT, in all evaluation time (Figure 2). This reinforces further mechanization used in tillage altering the physical characteristics in relation mainly to the ground structure where the amount of pores in the surface layer is reduced by breakdown of soil particles, being more prominent as the clayey is the soil. 


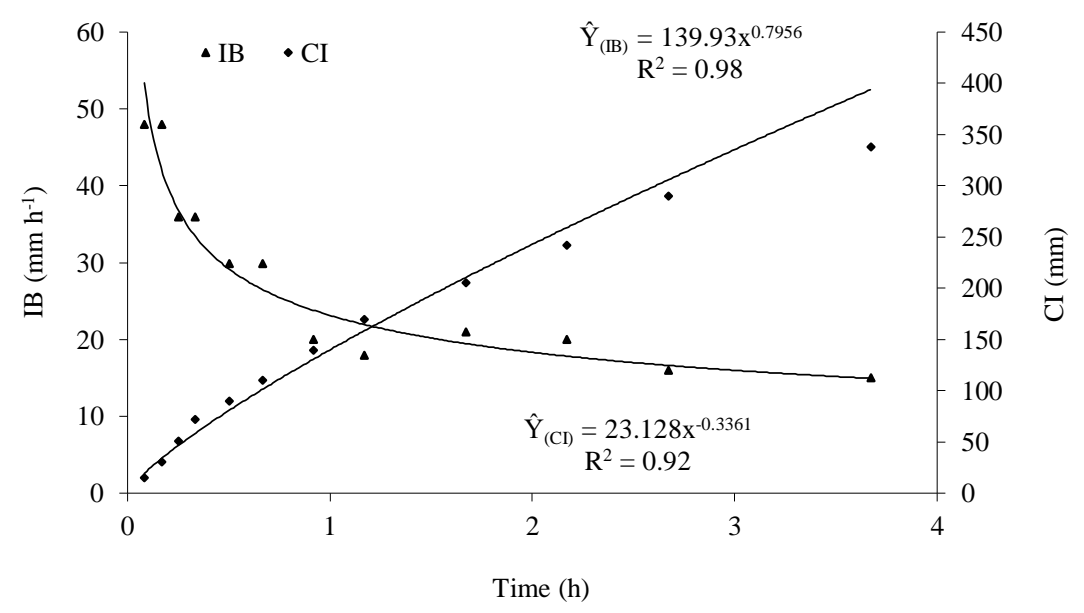

Figure 2. Basic infiltration velocity and accumulated infiltration of soil under minimum tillage in the California irrigated perimeter, Canindé do São Francisco, SE, agricultural year 2002 to 2004.

In Figure 3, it is possible to perceive the strong influence of the presence of an intense mechanization of the system CT in the internal water movement in soil, when compared to other types of management NT and MT. It can be observed that the values of IB e CI are much smaller, reaching twice as low as MT, especially at the beginning of the measurement, and approximately three times lower than in NT.

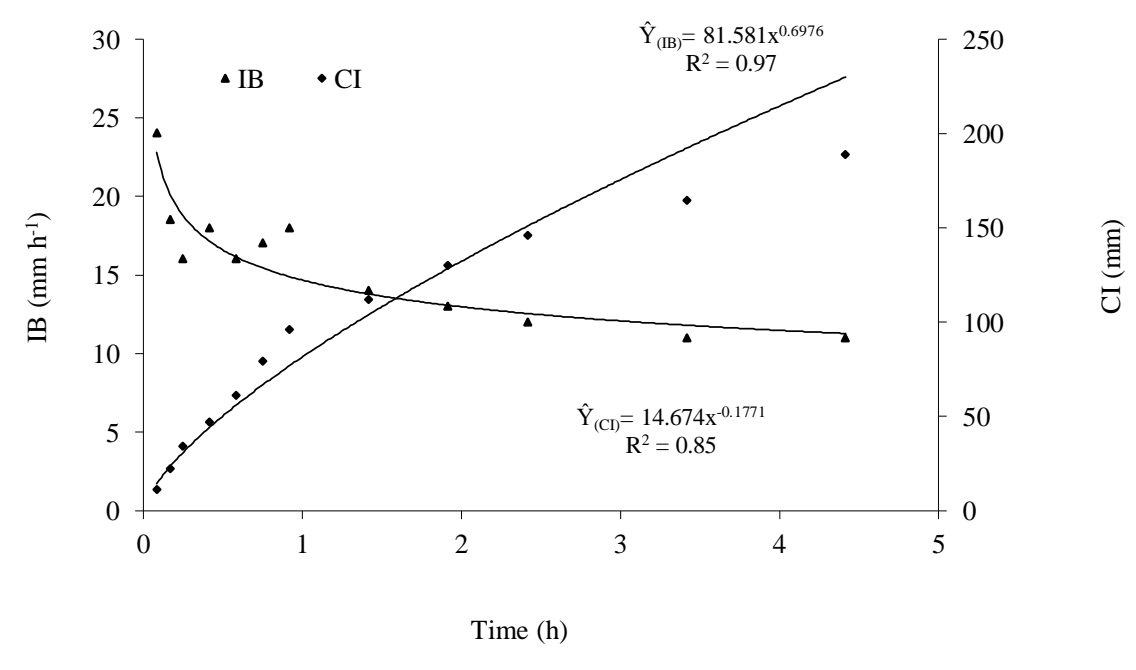

Figure 3. Basic infiltration velocity and accumulated infiltration of soil under conventional tillage in the California irrigated perimeter, Canindé do São Francisco, SE, agricultural year 2002 to 2004.

This behavior expressed as mechanization, facing intense tillage, compromises the soil structure, causing a significant reduction in macropores, which in turn is related to the dynamics of water and 
aeration in the soil profile (AGUIAR NETTO et al., 2006a), hindering the development of the root system of the crops and making these soils more susceptible to erosion due to their lower permeability.

Furthermore, Saxton \& Rawls (2006) report that the hydrological processes of infiltration and redistribution of water in the soil are also affected by the salinity, through chemical inductions that alter its structure and aggregation. This can be evidenced in this work by the structure in subangular blocks with strong resistance in the horizon $\mathrm{B}$, suggesting that the lower values of IB and CI this culture system may be associated with the value of EC of saturated paste found in depth $20.0-30.0 \mathrm{~cm}$.

It was found that the values of IB and CI are variables that correlate with the soil structure, being affected when the soil is submitted to constant revolving. This is evident in the most conservation systems, with emphasis on the NT, the absence of mobilization or not use of mechanization, and then to the system MT, due to the little change, allowing greater favoring of the structure of the soil particles, potentiated by the positive performance of the maintenance of dead cover by the accumulation of cultural remains.

The data presented in Figures 1, 2 and 3 indicate that, probably the system NT promoted a better aggregation of the soil resulting from the greater stability of its aggregates promoted by the organic matter, also leading to a greater amount of macropores, responsible for the conduction of air and water along the soil profile, mainly in the superficial layer where the absence of mechanization contributes to better structuring of this layer.

In the management system of MT, since less intense mechanization is promoted, by means of a light harrowing, the values of the IB were lower at the beginning of the measurement when compared to the NT, as well as the volume of water infiltrated during the entire period of analysis. The system CT presented the lowest rate of infiltration and accumulated infiltration among management systems, evidencing the negative effects of systems that use intense soil mobilization. Similar behavior was observed by Klein \& Libardi (2002), which determined an infiltration rate in forest soil with values of $1390 \mathrm{~mm} \mathrm{~h}^{-1}$ and in cultivated area with NT for 15 years $63 \mathrm{~mm} \mathrm{~h}^{-1}$, indicating a significant reduction of IB in terms of land use and management.

The low average concentrations of EC, between 1.01 and $2.53 \mathrm{dS} \mathrm{m}^{-1}$ and the low correlation with soil preparation types, indicate that the concentration of salts in the soil solution studied was not high enough to affect the IB and accumulated infiltration. Silva et al. (2004) also did not observe alterations in the soil structure in the concentrations of salts in the extension of values found in this work. 
The infiltration values identified in the California Project area may be useful to guide irrigation management in order to avoid excesses and water deficits in the soil, and the best cropping system to be adopted in future projects, with emphasis on improving profile infiltration of the soil and its structure, preventing the beginning of soil degradation processes.

In land use and water resource management, especially in this Hydrographic Region where the role of irrigation is significant, water and soil management in irrigation practice is vital for the rational, efficient and effective use of water. For this, the knowledge of the physical parameters of the water behavior in the soil is essential, and some of them are difficult to obtain, such as the great difficulty of determining the basic infiltration velocity by the different types of soils associated with a vegetation cover.

The limited existing studies, either for erosion control or surface runoff estimation, the hydrological classification based on the soil characteristics appears as a viable solution. The use of water and soil resources in the Hydrographic Region is limited more in the availability of water resources than in soils, therefore, it is necessary to be continuously and systematically evaluating the behavior and interactivity between these two resources, for a better knowledge of their uses (IBAMA, 2006).

The contribution of organic matter, due to the incorporation of the vegetal remains of the previous crop and the absence of preparation or soil rotation, effectively promoted the improvement of the physical attributes of the soil. Possibly, a better aggregation of its particles resulting from the cementation of the same naturally promoted by the organic matter, led to the occurrence of a larger amount of macropores, which in turn are pores responsible for conducting air and water along the soil profile.

The presence of larger pores in larger numbers should have contributed to higher values of IB in the first minutes, and of CI over time measured in NT, when compared to the management system MT and CT.

In the system MT of soil management, whose practices of mechanization and cultural management were used a slight gradation, not exceeding the superficial $15 \mathrm{~cm}$ of the soil and incorporation of the cultural remains, respectively, it was observed lower values of IB and CI when compared to NT, but higher than the CT system. It was then verified that a less intense mechanization contributed to different values of IB and CI of the MT when compared to NT and CT.

In the conventional system, mechanization was performed with greater intensity when compared to MT. It was observed that their values of IB and CI are significantly smaller than the NT and MT, since the lack of mechanization in the NT or the little change as in the MT, allowed a greater efficiency in the 
structuring of the soil particles, aided by the incorporation of cultural remains. The organic matter and the deeper root system have played a very important role in the structuring of the soil.

In the soil rehabilitation experiment, in an area with an advanced salinization process, the very low IB and CI, in the area where the salinization encounters very high levels of EC, made it impossible to develop any agricultural or livestock activities. It was observed that these parameters in the moments of realization of the infiltration tests, decreasing and after three hours, it was observed that its IB did not exceed $5 \mathrm{~mm} \mathrm{~h}^{-1}$. It was verified that the volume of water infiltrated until the end of the last reading did not exceed $25 \mathrm{~mm}$, fact explained by the dispersing action of sodium, when found in the soil at high levels and by the low efficiency of the drainage to that area was submitted.

In this area, the prevention of salinization involves the survey of soil properties, the proper management of irrigation and the planning of an efficient drainage system. On the other hand, where these preventive measures were not taken or were not efficient, the recovery of the productive capacity of the soils can be obtained by the use of techniques such as the use of chemical correctives and application of water slides for the leaching of the salts. It is clear that the producer cannot lose sight of the fact that salinization comes in addition to reducing its production, jeopardizing the future use of the area, besides promoting a process of environmental degradation and an onerous recovery. In the perimeter of California, the process of salinization occurs due to the richness of the soils in salts, the inadequate management of irrigation, a precarious drainage system and in many non-existent lots with no relation to irrigation water quality.

The infiltration values observed serve as the basis for the planning of the most beneficial cropping and management system, which are fundamental attributes for the prevention or even recovery of the soil system, vulnerable to the processes of salinization and erosion.

\section{CONCLUSIONS}

The no-tillage system provides improvements in water retention capacity and soil infiltration capacity, under the edaphoclimatic conditions of the study.

The behavior of water infiltration was more favorable in the most conservationist management systems MT and NT, the contribution of organic matter from the cultural remains and the low soil movement, resulting in improvements in its structure. 
Little or no soil rotation in conservation systems increases water infiltration, due to the better structuring of the soils due to the absence of mechanization.

The better soil structure, besides promoting a better drainage in the soil profile, creates conditions that effectively hinder the erosive processes that can occur in a 2:1 clay-rich, pedogenetically rich Luvissolo.

There was better percolation of the water in the soil in areas managed with no-tillage and / or minimum cultivation and higher values of infiltration velocity and accumulated infiltration.

Higher infiltration rates allow greater flexibility of irrigated slides and minimize the effect of salt concentration, avoiding risks of salinization of the soil, besides preventing the onset of erosive processes.

\section{REFERENCES}

AGUIAR NETTO, A. O.; MACHADO, R.; BARRETO, M. C. V.2006a. Diagnóstico do processo de salino-sodificação no Perímetro irrigado Jabiberi-SE. Revista Irriga. Botucatu, v. 11, n. 04, p.448459.

AGUIAR NETTO, A. O.; MACHADO, R.; VARGAS, M. A. M. 2006b.Sustentabilidade do Perímetro irrigado Jabiberi-SE. Revista RA'E GA. Curitiba, n. 12, p. 153-159.

ANTONINO, A. C. D.; SAMPAIO, E. V. S. B.; DALL'OLIO, A.; SALCEDO, I. H. 2000. Balanço hídrico em solo com cultivos de subsistência no semiárido do nordeste do Brasil. Revista Brasileira de Engenharia Agrícola e Ambiental. Campina Grande, v. 4, n. 1, p. 29-34.

AYERS, R. S.; WESTCOT, D. W. 1994. Water Quality for agriculture. 3rd. ed. Rome: FAO, 174 p. (FAO. Irrigation and Drainage Paper, 29).

BRASILEIRO, R. S.2009. Alternativas de desenvolvimento sustentável no semiárido nordestino: da degradação a conservação. Scientia Plena, São Cristóvão, v. 5, n. 5, p. 1 - 12.

CHAVES, L. C. G.; ANDRADE, E. M. DE; CRISOSTOMO, L. A.; NESS, R. L. L.; LOPES, J. F. B. 2006. Risco de degradação em solo irrigado do Distrito de Irrigação do Perímetro Araras Norte, Ceará. Revista Ciência Agronômica, Fortaleza, v. 37, n. 3, p. 292 - 298.

DIAS, N. D. S., DUARTE, S. N., GHEYI, H. R., DE MEDEIROS, J. F., \& SOARES, T. M.2005.Manejo da fertirrigação e controle da salinidade do solo sob ambiente protegido, utilizandose extratores de solução do solo. Revista Brasileira de Engenharia Agrícola e Ambiental, Campina Grande, v. 9, n. 4, p. 496-504, 2005.

EMBRAPA - Empresa Brasileira de Pesquisa Agropecuária. 1997. Centro Nacional de Pesquisa de Solo. Manual de métodos da análise de solo. 2.ed. Rio de Janeiro, 212p.

EMBRAPA- EMPRESA BRASILEIRA DE PESQUISA AGROPECUÁRIA. 2009. Manual de análises químicas de solos, plantas e fertilizantes. Brasília, DF: Embrapa Informação Tecnológica.

FERREIRA, P. A.; MOURA, R. F.; SANTOS, D. B. DOS; FONTES, P. C. R.; MELO, R. F.DE. 2006. Efeitos da lixiviação e da salinidade da água sobre um solo salinizado cultivado com beterraba. Revista Brasileira de Engenharia Agrícola e Ambiental, Campina Grande, v. 10, n. 3, p. 570578. 
FERREIRA, D.F.S. 2011. SISVAR 4.3. Available at: <http:://www.dex.ufla.br>. Access in Nov 25, 2016.

GHEYI, H. R. 1997. Efeitos dos sais sobre as plantas. In: FAGEIRA, N. K. Manejo e controle da salinidade na agricultura irrigada. Campina Grande, PB: UFPB, p. 125-131.

GHEYI, H. R.; MEDEIROS, J. F.; BATISTA, M. A. F.1991. Prevenção, manejo e recuperação de solos salinos e sódicos. Mossoró: ESAM, 70p.

IBAMA.2006. Caderno da Região Hidrográfica do São Francisco / Ministério do Meio Ambiente, Secretaria de Recursos Hídricos. - Brasília: MMA, 148 p.

KLEIN, V.A.; LIBARDI, P.L.2002. Condutividade hidráulica de um Latossolo Roxo, nãosaturado, sob diferentes sistemas de uso e manejo. Ciência Rural, Santa Maria, v. 32, p. 945-953.

KOSUTIC, S.; HUSNJAK, S.; FILIPOVIC, D.; BOGUNOVIC, M.2001. Influence of different tillage systems on soil water availability in the Ap- horizon of an Albic Luvisol and yield en north-west Slavonia, Croatia. Die Bodenkultur, Austria, v. 52, n. 3, p. 215-223.

KUTÍLEK, M. Soil hydraulic properties as related to soil structure. 2004.Soil \& Tillage Research, Amsterdam, v. 79, p. 175-184.

LACERDA, C. F.; SOUSA, G. G.; SILVA, F. L. B.; GUIMARÃES, F. V. A.; SILVA, G. L.; CAVALCANTE, L. F.2011. Soil salinization and maize and cowpea yield in the crop rotation system using saline waters. Engenharia Agrícola, Jaboticabal, v. 31, n. 4, p. 663 - 675.

LIMA, J. R. S.; ANTONINO, A. C. D.; LIRA, C. A. B. O.; SILVA, I. F. 2005. Estimativa da evapotranspiração em uma cultura de feijão Caupi, nas condições do Brejo Paraibano.

Agropecuária, Areia, v. 26, n. 2, p. 86-92.

LIPIEC, J.; KUS, J.; SŁOWIŃSKA-JURKIEWICZ, A.; NOSALEWICZ, A. 2006. Soil porosity and water infiltration as influenced by tillage methods, Soil \& Tillage Research, Amsterdam, v. 89, p. 210-220.

LOPES, J. D. B.; ANDRADE, E. M. DE; CHAVES, L. C. G.2008.Impacto da irrigação sobre os solos de perímetros irrigados na Bacia do Acaraú, Ceará, Brasil. Engenharia Agrícola, Jaboticabal, v. 28, n. 1, p. $34-43$.

MAAS, E. U. Crop tolerance. 1984. California Agriculture, California, v. 38, p.20-21.

MACEDO, L. S.; MENINO, I. B.1998. Monitoramento de sais na água e nos solos irrigados do projeto Vereda Grande, PB. Revista Brasileira de Engenharia Agrícola e Ambiental, Campina Grande, v. 2, n. 1, p. 262-267.

MACHADO, R.; AGUIAR-NETO, A. O.; CAMPECHE, L. F. DE S. M.; BARROS, A. C.2007.Efeito da salinidade em características físico-hídricas em solos salino-sodilizados no perímetro irrigado Jabiberi-SE. Revista Brasileira de Agricultura Irrigada, Fortaleza, v. 1, n. 1, p. 15-19.

MENDES, J. S.; CHAVES, L. H. G.; CHAVES, I. B. 2008.Variabilidade temporal da fertilidade, salinidade e sodicidade de solos irrigados no município de Congo, PB. Revista Brasileira de Ciências Agrárias. Recife, v. 3, n. 1, p. 13-19.

MENDONÇA, E. de S.; MATOS, E. da S. Matéria orgânica do solo: Métodos de análises. Viçosa: UFV, 2005. $107 \mathrm{p}$.

RUIZ, H. A.; SAMPAIO, R. A.; OLIVEIRA, M. DE; FERREIRA, P. A. 2006. Características físicas de solos salino-sódicos submetidos a parcelamento da lâmina de lixiviação. Revista de la Ciencia del Suelo y Nutrición Vegetal, Chile, v. 6, n. 3, p. 1 - 12.

SANTANA, M. J. DE; CARVALHO, J. DE A.; SOUZA, K. J. DE; SOUSA, A. M. G. DE; VASCONCELOS, C. L.; ANDRADE, L. A. DE.2007. Efeitos da salinidade da água de irrigação na brotação e desenvolvimento inicial da cana-de-açúcar (Saccharum spp) e em solos com diferentes níveis texturais. Ciência Agrotecnologia, Lavras v. 31, n. 5, p. 1470 - 1476. 
SAXTON, K. E.; RAWLS, W. J.2006. Soil Water Characteristic Estimates by Texture and Organic Matter for Hydrologic Solutions. Soil Science Society American Journal. Madison, v. 70, p. 15691578.

SILVA, E. F.; ASSIS JR., R. N.; NESS, R. L. L. 2004. A qualidade da água de irrigação e atributos físicos do solo: o caso de um Neossolo Flúvico. In: OLIVEIRA, T.S. (org.). Solo e água: aspectos de uso e manejo. Fortaleza: Departamento de Ciências do Solo, UFC, p. 274-297.

SILVA, J. C. A.; ANDRADE, A. P.; SILVA, I. F.2006.Avaliação da infiltração da água no solo como indicador de modificações edáficas em três sistemas de manejo. Agropecuária Técnica, Areia, v.27, n.2, p.85-91.

VALLADARES; G. S.; FARIA; A. L. L.2004.SIG na análise do risco de salinização na Bacia do rio Coruripe, Al. ENGEVISTA, Rio de Janeiro, v. 6, n. 3, p. 86-98.

Received in September 27, 2016

Accepted in November 06, 2017 